\title{
Constraints to strengthening public sector accountability through civil society: the case of Morocco
}

\author{
Sylvia I. Bergh \\ Institute of Social Studies \\ Kortenaerkade 12 \\ 2518 AX The Hague, The Netherlands \\ E-mail: bergh@iss.nl
}

\begin{abstract}
This paper discusses the extent to which civil society contributes to strengthening public sector accountability in Morocco. The main argument in this paper is that despite a few recent encouraging examples, civil society's role in strengthening public sector accountability remains limited at both the national and local levels. This is due to three main reasons. The first relates to certain characteristics of the Moroccan governance system, including the dominance of upward accountability mechanisms, given the unique position of the King. The second set of reasons refers to certain internal features of the Moroccan civil society. The third reason can be found in civil society's position with regard to its external environment, i.e., the nature of its relationships with the public sector in the form of both local governments and ministerial public administrations.
\end{abstract}

Keywords: public sector accountability; civil society; governance; human rights; corruption; Morocco.

Reference to this paper should be made as follows: Bergh, S.I. (2009) 'Constraints to strengthening public sector accountability through civil society: the case of Morocco', Int. J. Public Policy, Vol. 4, Nos. 3/4, pp.344-365.

Biographical notes: Sylvia I. Bergh is a Lecturer in Development Management and Governance at the Institute of Social Studies in the Hague, the Netherlands. She is currently completing a DPhil in Development Studies at the University of Oxford, UK, focusing on decentralisation and local governance in Morocco. Previously, she worked at the World Bank, both in the President's Office in Washington, DC and in the Morocco Country Office. Her academic background includes a strong focus on the Middle East/North Africa region; having gained a First Class degree in Arabic and International Relations from the University of St. Andrews in Scotland in 1999, she obtained an MPhil in Modern Middle Eastern Studies from the University of Oxford in 2001.

\section{Introduction}

This paper discusses the extent to which civil society contributes to strengthening public sector accountability in Morocco. Morocco is an interesting case study, as the country is widely perceived as being at the forefront and a model in terms of democratic reform in 
the Middle East and North Africa region. Its civil society is seen as one of the most dynamic in the region (Malka and Alterman, 2006, p.72; Chammari and Kéfi, 2006). The main argument in this paper is that despite a few recent encouraging examples, civil society's role in strengthening public sector accountability remains limited at both the national and local levels. This is due to three main reasons. The first relates to certain characteristics of the Moroccan governance system, including the dominance of upward accountability mechanisms, given the unique position of the King. The second set of reasons refers to certain internal features of Moroccan civil society, especially with regard to its internal divisions. The third reason can be found in civil society's position with regard to its external environment, i.e., the nature of its relationships with the public sector in the form of both local governments and ministerial public administrations, which at best amount to 'co-production' rather than 'co-governance' arrangements.

In order to make these points as coherently as possible, the paper is structured into four main sections. The first section summarises the main features of the Moroccan governance system with regard to the existing vertical and horizontal accountability channels. The second section provides some reasons for the growth of civil society in the country and discusses the evolution of the legal framework. The third section provides a typology of Moroccan civil society and highlights its diversity in terms of its objectives, as well as the limited scope for pro-accountability alliances. This section also describes some recent examples where it could be said that civil society has contributed to strengthening public sector accountability, in particular, the work of the Equity and Reconciliation Commission and Transparency Maroc. The final section briefly examines the recent changes in the legal framework that encourage state-civil society partnerships at various levels and critically assesses their accountability aspects in practice.

In terms of its conceptual framework, accountability is understood here as involving three main elements:

1 answerability, or 'the obligation of the public officials to inform about and to explain what they are doing'

2 enforcement, or 'the capacity of accounting agencies to impose sanctions on the power holders who have violated their public duties'

3 receptiveness, or 'the capacity of the officials to take into account the knowledge and opinions of the citizens' (Schedler, 1999; World Bank, 2004, pp.7-8).

These three elements point to the distinction between legal accountability and performance accountability. The first category refers to keeping the public officials in check by making sure that they respect the legal order, both in their administrative tasks and in their relationship to society at large. The second category involves the successful implementation of policies designed to benefit the public in general, with a particular emphasis on the policies that attend to the needs of the poor. Legal accountability, thus, has to do with respecting of the rule of law and preventing the abuse of public office, while performance accountability involves questions of efficiency, effectiveness and fairness (World Bank, 2004, p.8).

As for the role of civil society, it can reinforce the structures of accountability in three different ways: 
1 direct monitoring and pressure from civil society actors, as well as popular votes (in the form of surveys that monitor the effectiveness of public services, media exposés of bureaucratic wrongdoing and the organisation of plebiscites and referendums on particular issues or policies) can improve the vertical accountability of the public officials to the public

2 pressure from civil society on oversight agencies (such as ombudsmen) to do their jobs effectively can strengthen the effectiveness of the existing horizontal accountability mechanisms within the state

3 civil society actors can participate directly in the government's own institutions of accountability, for example, through 'co-governance' mechanisms. ${ }^{1}$

However, both state and society actors usually play crucial roles in bringing about these three forms of accountability. Plebiscites and referendums require both the support of the legislature and a vibrant civil society that is willing to get the vote out. Mechanisms like human rights ombudsmen require both social pressure and enlightened bureaucratic action. 'Co-governance' mechanisms also depend on the willingness of the government to open up its accounts to independent actors, as well as the will of civil society participants to take the time to look over and evaluate these accounts (World Bank, 2004, pp.9-10).

\section{Accountability in the Moroccan governance system}

Let us first consider the traditional ('vertical' and 'horizontal') mechanisms of ensuring public sector accountability in the Moroccan context. 'Vertical' accountability mechanisms require government officials to appeal 'downwards' to the people at large (World Bank, 2004, p.9). Ackerman (2004, p.448) argues that free and fair elections are one of the most powerful 'vertical' accountability mechanisms. ${ }^{2}$ However, they have at least three structural problems:

1 they only hold elected officials accountable, whereas the vast majority of the public officials are appointed bureaucrats

2 they cannot give clear accountability signals to individual office holders

3 they encourage politicians to favour patronage, rather than defend the public interest.

The empirical context in Morocco adds another layer of problems: although elections have recently become relatively 'free and fair', the voter turnout is low (it plunged to a historical low of $37 \%$ in the 2007 legislative elections down from $51 \%$ in the 2002 elections and 58\% in 1997) (Hamzawy, 2007, p.1). Individual candidates as well as political parties are clientelistic, rather than being held accountable to a specific policy programme (Axtmann, 2003, p.6; Willis, 2002a-b).

An underlying factor for weak 'vertical' accountability could also be that relatively few people actually pay taxes and hence, might not feel a strong incentive to hold the public sector accountable for its spending. Only 2.4 million people were subject to the general income tax in 2001, representing less than $50 \%$ of the active population, and only $19 \%$ of them actually paid this tax. This is because two-thirds of the private sector 
employees are below the taxation threshold (FEMISE, 2004, p.126ff.). Similarly, local municipalities are very heavily dependent on Value-Added Tax (VAT) transfers for their finances and do not collect any significant local tax revenues (DGCL, 2004).

As for the media, during King Mohamed VI's first year alone (1999-2000), eight local and international newspapers were censored for publishing stories on corruption within the armed forces and high administrative circles and for questioning Morocco's policies in the disputed Western Saharan territories (Maghraoui, 2001, p.14). Despite a reform of the press law in 2002 which has increased press freedoms (at least on paper), several journalists who were seen to have crossed certain 'red lines' have recently been prosecuted, resulting in heavy fines or even prison sentences (Malka and Alterman, 2006, pp.56-57).

With regard to the mechanisms of 'horizontal' accountability, these are mechanisms that require public officials and agencies to report 'sideways' to other officials and agencies within the state itself. Again, they have a number of inherent problems in developing countries, such as their lack of funding, limited enforcement capacity and the overall weakness of the rule of law (Ackerman, 2004, p.449). In Morocco, the performance of the public sector administration is seldom measured and there are no explicit sanctions for poor performance. A number of new accountability mechanisms have been created since the 1990s, including an ombudsman ('Diwan al-Madalim'), administrative courts and corruption control agencies. ${ }^{3}$ They are of limited effectiveness though, as access to information is restricted. For example, the audits performed by the administrative courts (Cour des Comptes) are only released to the concerned parties (Cherkaoui and Ben Ali, 2007, p.750). Moreover, these official accountability mechanisms are often bypassed. Catusse (2002, p.17ff.) points out that it is the unaccountable financial audit teams in the Ministry of the Interior that carry out the investigations against corrupt local councillors, rather than the administrative courts.

Most importantly, the Moroccan parliament has very limited influence on the formulation of the government budget (Loi de finance) and its evaluation reports (Lois de règlement) are submitted only several years after the budget year in question (Maghri, 2007; Denoeux and Desfosses, 2007, p.97). Referring to the creation of a second, upper, house in 1997, Sweet (2001, p.24) argues that the Moroccan parliament is a "classic pseudo-democratic institution", as it enhances the power of the regime rather than limiting it. ${ }^{4}$ However, Denoeux and Desfosses (2007, p.94) note that the Moroccan legislature has recently asserted its constitutional oversight prerogatives more vigorously than ever before. For example, the oral and written questions submitted by Members of Parliament (MPs) frequently highlight deficiencies in the government's actions, and ministers who are called upon by Parliament are forced to account for the shortcomings of certain public entities or policies. Another important oversight achievement of the Moroccan Parliament since 2000 was its role in shedding light on two corruption scandals, one related to a state-owned bank, the Crédit Immobilier et Hôtelier (CIH) and the other to the country's social security fund, the Caisse Nationale de Sécurité Sociale (CNSS).

At the local level, the author's fieldwork in Al Haouz province showed that the political opposition in the local government (commune) councils is relatively powerless to hold the ruling majority to account. This is mainly due to the lack of access to the budget and other relevant information and to influential council positions. As a councillor 
and former president of a municipal council put it, the main drawback of the new 2002 Municipal Charter is that it enshrines the 'dictatorship of the majority', which means that "if you have the majority in the commune council you can do anything you like".

These deficiencies in the 'vertical' and 'horizontal' accountability mechanisms can be explained by the position of the King, since he is by constitution (Article 19) the 'supreme representative of the nation' and has the power to terminate the tenure of any MP, dissolve the Parliament and call for new elections. ${ }^{5}$ He may also revise or veto any piece of legislation, circumvent the Parliament entirely by acting through a rule or decree and he also appoints the Prime, Foreign, Interior, Justice and Islamic Affairs Ministers. Most importantly, the King heads a 'royal cabinet' composed of former politicians, business leaders and army chiefs, which runs in parallel to the government. This 'second cabinet' is widely known as the focal point for the Makhzen, the popular name given to the Moroccan establishment. Moreover, the frequent use of royal decrees (dahir), as well as the unchecked power of many appointed government officials (all the regional and provincial governors are directly appointed by the King), means that the decision-makers are widely perceived to be unaccountable. Most political parties are weak and often show greater loyalty to the King than to their constituents. An important exception here is the moderate Islamist party, the Justice and Development Party (PJD), which now holds 46 out of 325 seats and has developed a broad popular support base by campaigning on a platform of transparency and accountability (Hamzawy, 2007; Malka and Alterman, 2006, pp.55-56, 72; Oxford Business Group, 2005). In the social policy arena, the King has, under the guise of 'democratic transition' and 'efficiency', established semipublic institutions (such as the Mohamed V Foundation, the Hassan II Fund and the Social Development Agency), which are not accountable to the Parliament (Catusse and Vairel, 2003, p.90).

Having briefly described the nature and performance of the main accountability mechanisms in the Moroccan governance system, I will now examine the reasons for the growth of Moroccan civil society, as well as the recent changes in the legal framework governing Civil Society Organisations (CSOs). This should help us to establish more precisely the scope for civil society activism with regard to public sector accountability.

\section{The growth of Moroccan civil society and the current legal framework}

Given the predominant position of the King, some observers have cast doubt on the existence of a civil society in Morocco, since it could be argued that the Moroccan society is composed of subjects rather than citizens (Kasriel, 2006, pp.85, 87; Espace Associatif, 2003, p.122; Layachi, 1998, pp.15, 41; Bourjeois and El Kam, 2000, p.13). ${ }^{6}$ Nevertheless, the existence of a huge number of civil society actors cannot be denied: it is estimated that there are between 40000 to $70000 \mathrm{CSOs}$, although not all of them are active (Ayee et al., 2004, p.56; Herzenni, 2006, p.250; Chammari and Kéfi, 2006; UNDP and Périer, 2005, p.12).

Historically, i.e., for three decades following Morocco's independence, associations were very closely tied to the political process and the political struggle between the political parties and the monarchy. Their lack of autonomy meant that they could not articulate any independent interest or purpose and were repressed whenever the political party it was affiliated with was repressed, resulting in the weakening of associational 
activities (Sater, 2002, pp.104-106; Mouaqit, 2004, p.92ff.). However, since the mid-1980s, the associative sector has grown considerably. It is possible to distinguish four main reasons for this growth. ${ }^{7}$

The first reason is donor and other external pressures. The adoption of Structural Adjustment Policies in 1983 strengthened the position of actors within business and civil society that pressed for new and more transparent rules in both the economic and political arenas. At the same time, the Moroccan regime required greater international respectability' to secure access to international loans, foreign investment and trade agreements (especially the association agreement with the European Union). As Hegasy (1998, p.15) put it rather crudely, "Morocco no longer wants to be the barbarous butcher of Gibraltar." The critical reports of Amnesty International and the US State Department also contributed to the international pressure. The regime was therefore forced to confront its legacy of past human rights abuses and show increased tolerance towards public discussion (Denoeux, 2000, p.174; Denoeux and Gateau, 1995, p.31; Denoeux and Maghraoui, 1998, p.115; Belkouch, 2006, p.36).

Similarly, starting in the mid-1990s, donors put pressure on the Moroccan government to increase transparency in public administration by curbing corruption. They did so by publishing numerous surveys and studies documenting the enormous economic and social costs of corruption in Morocco. Donors also contributed to making corruption a legitimate topic for public discussion by presenting it as a global disease that afflicts numerous countries, not just Morocco. They often worked in direct cooperation with the newly established advocacy Non-Government Organisations (NGOs) such as Maroc 2020 and Transparency Maroc (see below; Denoeux, 2000, p.174ff.). ${ }^{8}$

Second, the lack of credibility of the political parties, their declining power to articulate societal interests and the fact that they no longer worked at the grassroots level led to the appearance of a political vacuum. Islamists and secular advocacy NGOs filled this vacuum and, in turn, partly replaced the political parties. Indeed, many associations became havens for a large number of former members of leftist political organisations (Naciri et al., 2004, pp.115-116, 129-130; Sater, 2002, p.108).

The decline of the political parties is related to the third reason, namely, the (implicit) objective to stem the rising tide of Islamism, as is illustrated by the work done by specific secular groups such as the Committee for the Rights of Women (CIOFEM) and 'Springtime for Equality' (Collectif du printemps de l'égalité), established in 2001 as part of the campaign for a reform of the Family Code (Moudawana). The government's recent partnership policy with the 'secular' associative movement (see below) can also be seen in this light (Cavatorta, 2006, p.16; Naciri et al., 2004, p.93; Malka and Alterman, 2006, p.71).

Fourth, there has been a considerable change in the political sphere with regards to freedom of association since the accession of King Mohamed VI in 1999 and the 'democratic transition', more generally (Ayee et al., 2004, p.55; Cavatorta, 2006, p.216). However, an examination of the recent changes in the legal framework governing associations shows that they do not significantly enhance the CSOs' role in enhancing public sector accountability.

The Law on Public Liberties of 1958 (Juris-Classeur Marocain, 1958) accorded the right to associate to everyone. It defines 'association' as the "agreement by which two or more persons pool their knowledge or activity in a permanent manner for a purpose other than sharing profits" (author's translation). The 1958 law was amended by the dahir of 
10 April 1973. Since many members of the underground leftist political opposition had found refuge in associations, the 1973 dahir gave significant powers to the public authorities to sanction and dissolve associations (Elbayar, 2005; Bourjeois and El Kam, 2000, p.9; Piriou-Sall and Sallier, 1998, p.24). For example, the amended code required the approval of the Ministry of the Interior before the holding of any meeting with the purpose of creating an organisation (i.e., the association needed to submit a 'déclaration préalable' and wait for a receipt). The authorities used this provision to conduct investigations and refuse permission to persons or organisations that might have advocated sensitive causes, such as the Berber (Amazigh) activists, the Islamic associations and parties and the leftist human rights and political groups. The amended law also introduced severe penalties of up to two years in prison. Most importantly, the government was given the right to suspend or dissolve an association based on vague criteria, such as "if it seems that the activity of the association might disturb public order" (Herzenni, 2006, p.227; Layachi, 1998, p.43; Carnegie Endowment for International Peace and FRIDE, 2006, p.9; Filali Meknassi, 2002, p.15; FEMISE, 2004, p.192; Louissi, 2001, p.59ff.).

After intense lobbying by civil society, the Parliament approved a new law on associations on 11 April 2002. ${ }^{9}$ This new law strikes a balance between opening up towards civil society and the maintenance of 'soft' state control. In particular, Article 5 now stipulates that every association has to submit a declaration of its constitution to the local representative of the Ministry of the Interior (the Caid), but receive a dated and stamped (provisional) receipt right away. The Caid then sends a copy of the declaration to the tribunal and issues a definitive receipt to the association after a maximum of 60 days. However, the association is considered legal even if it does not receive such a receipt after this delay. The penal sanctions are also much reduced now and the provisions concerning dissolution on the grounds of 'disturbing the public order' and dissolution by decree have been struck; dissolution can now only take place through the judicial system.

The 2002 law introduced some additional bureaucratic control measures though; in addition to the national identity card, the founding members of the association now also have to submit an extract of their criminal record and still pay fees for the legalisation of copies. These can consume a considerable amount of resources (which would have been more productively used for the association's activities), especially when compared to the modest budgets of the local village associations in rural areas. ${ }^{10}$ Furthermore, the current legal framework gives a substantial role to the Caid, as it is his office that is in charge of all the administrative declarations required for the constitution of associations and the renewal of their committees. The Caid is also responsible for granting permissions for public gatherings, including the public events organised by associations (Filali Meknassi, 2002, pp.26-28; RTI, 2002, p.3; World Bank, 2003, p.9). Hence, he can still stifle, or at least delay, the creation of Amazigh associations or otherwise critical associations, as the author observed in $\mathrm{Al} \mathrm{Haouz} \mathrm{province.} \mathrm{The} \mathrm{Caid} \mathrm{also} \mathrm{has} \mathrm{an} \mathrm{important} \mathrm{oversight} \mathrm{role}$ over the local government (and is, in fact, co-chairing its sessions) and is often allied with its political majority. Hence, if a local association wants to hold the local government to account, it needs to bring up considerable courage, as it risks not only a confrontation with certain council members but also with the Caid, which could result in it being harassed or otherwise obstructed in the future (author's fieldwork observations). ${ }^{11}$ 
In sum, therefore, the current legal framework is less restrictive than before. However, it still reserves considerable leverage for the local representative of the Ministry of the Interior.

\section{Assessing the scope for public sector accountability through civil society}

The preceding discussion indicates that there is no uniform 'civil society' in Morocco. I therefore present a brief typology of the different types of CSOs that are considered to be part of it and try to assess each of them separately in terms of its ability and motivation to strengthen public sector accountability. I will focus, in particular, on some recent success stories found in the 'pro-democracy' sector. However, the main point of this section is that such examples remain few, due to the low priority given to accountability issues by the vast majority of CSOs, their very diverse objectives and the resulting difficulty for any long-term pro-accountability alliances to emerge.

It is possible to distinguish five main sectors of civil society in Morocco (adapted from Hawthorne, 2004, p.6ff.). The first sector includes the Islamist organisations. As mentioned earlier, the PJD is one of the few political parties that try to promote internal and external accountability. Similarly, the largest Islamic association in Morocco, the Jamiat al-Adl wal-Ihsan, calls for political institutions to become accountable. Given that it is publicly opposed to the monarchy, this is an illegal association. However, as Cavatorta (2006) points out, apart from providing important social services to the Moroccan shantytowns, there has been formal cooperation between this Islamist association and human rights groups on issues ranging from freedom of speech to the end of torture and legal protection for political prisoners. However, given that this association still faces important opposition from some quarters in the secular pro-democracy sector, combined with the fact that it is illegal to be a member of this association, its ability to hold the public sector to account is still rather limited.

The second type of CSOs in Morocco includes those mainly created by the Makhzen and is composed of associations concerned with culture, social identity and solidarity. Examples of such associations are the regional associations created by the intellectual bourgeoisie from 1985 onwards at the initiative of the palace. Their aims were to co-opt new (mainly urban) elites to counterbalance the influence of the political parties and to control the population due to security concerns. These associations, such as the Association Fes Saïs and the Association Ribat Al Fath, are therefore directly or indirectly controlled by the government and headed by former ministers or other people of the Makhzen. They organise ceremonies to celebrate national holidays, but have also contributed to national literacy campaigns and drinking water provision (see Lacroix, 2005, pp.168-169, for details on the Illigh regional association in the Souss area). Not surprisingly, they enjoy good relationships with the local representatives of the Ministry of the Interior, have the Status of Public Utility (ARUP) and get subsidies from the state (Santucci, 1991; Ayee et al., 2004, p.130; Chadli, 2001, p.25; Denoeux and Gateau, 1995, pp.21-22). Given their mostly cultural objectives and/or close relationships with the Makhzen, this type of association, therefore, does not have any discernable incentives to hold the public sector to account. 
The third sector includes membership-based professional organisations such as labour unions, professional syndicates and the chambers of commerce. Their main purpose is to lobby the government for higher wages and better working conditions. However, they are much better at blocking new laws than constructively contributing to new ones. After a decade of negotiations, the Labour Code was finally adopted in 2004 (Ben Ali, 2005, p.9ff.; Bergh, 2006, p.13). The three unions represent only $22 \%$ of the declared workers (Ayee et al., 2004, p.114) or even less (Carnegie Endowment for International Peace and FRIDE, 2006, pp.15-16; Cherkaoui and Ben Ali, 2007, pp.751-752). In contrast, the Employers' Federation (CGEM) has emerged as an important player on the scene, having been consulted for the most recent economic policy reforms such as Free Trade Agreements, etc. It has also lobbied for more transparency in the privatisation of public utilities and the reform of the public procurement laws. However, relations between the CGEM and Parliament lack an adequate structural framework. The CGEM has proposed a permanent liaison group, which could organise these relations to insure their permanence and regularity (Ben Ali, 2005, 6ff.; Denoeux and Desfosses, 2007, p.89).

The fourth type of CSOs consists of non-governmental service organisations, or what are often called 'service NGOs'. They deliver services such as microcredit, job training, educational assistance and community development to the public to complement, or in some cases, substitute for government services. The scope for this type of CSO to hold the public sector accountable will be discussed below. It is worth noting though that many volunteers who are involved in 'political' or 'pro-democracy' associations are also active in service NGOs, thereby combining the activist and pragmatic dimensions of volunteering (UNDP Maroc and Périer, 2005, p.14).

Fifthly, the large sector of pro-democracy or so-called 'advocacy' associations (including women's associations) is the sector that most outside democracy promoters and analysts usually think of as making up 'Moroccan civil society' (Ayee et al., 2004; Naciri, 1998; UNDP Maroc, 2006, p.65ff.; Hegasy, 1996, p.206ff.). The CSOs in this sector are behind the network that pushed for the adoption of the new law on associations, including a memorandum signed by over 500 associations addressed to the Prime Minister in January 1999. The Espace Associatif and other networks (which were or still are mostly funded by international donors such as the Friedrich Ebert Foundation) played an important role here and in subsequent battles, such as the monitoring of the 2002 legislative elections (Ayee et al., 2004: pp.72-73, p.112). ${ }^{12}$ The women's advocacy associations pushed for the reform of the Family Code, which was finally adopted in 2004. ${ }^{13}$ A further type of advocacy NGOs are the 'Berber' or Amazigh associations; their activities range from promoting the Tamazight language and culture in public arenas such as schools and the media and calling for its official recognition as a national language in the constitution, to claiming regional autonomy (Layachi, 1998, pp.57-58; Denoeux and Gateau, 1995, p.30). The fact that the King established a Royal Institute for Amazigh Culture (IRCAM) in 2001 can be seen as one of their most important achievements to date, although critics would interpret it as an example of co-optation by the Makhzen.

The main case study that will help demonstrate the effective limits to legal accountability in Morocco through civil society is taken from the field of human rights. Human rights organisations are among the oldest CSOs in Morocco. The Moroccan Defense League of Human Rights (LMDDH) was founded in 1972, followed by the Moroccan Human Rights Association (AMDH) in 1979, the Moroccan Human Rights Organization (OMDH) in 1988 and the Committee for the Defense of Human Rights $(\mathrm{CDDH})$ in 1992. While the LMDDH and the AMDH were controlled by the political 
opposition parties, the OMDH tried to stay politically independent. However, this only lasted until 1991, when the independent members left the organisation; it has since then been identified with the socialist party, the Union Socialiste des Forces Populaires (USFP) (Denoeux and Gateau, 1995, p.28). ${ }^{14}$

These organisations' demands for justice for political prisoners and human rights victims led the new King to set up an Indemnity Commission in 1999. However, none of the perpetrators were tried and former political prisoners and human rights activists heavily criticised the outcome. They set up the Moroccan Forum for Truth and Equity, whose calls eventually resulted in the establishment of the Equity and Reconciliation Commission (in French called Instance Equité et Réconciliation - IER) in 2004 (Slyomovics, 2005, p.21ff.). This commission was supposed to expose past abuses by the regime covering the period of 1956 to 1999 (Malka and Alterman, 2006, p.49). ${ }^{15}$ The IER met with more than 10000 claimants, victims and witnesses between January 2004 and November 2005. However, the senior government officials, particularly those in the secret services and the army, refused to cooperate with the commission's work, citing the ongoing 'war against terrorism'. The IER's final report contains a reparations plan and numerous recommendations, including the adoption of a national strategy to fight against impunity within the government and increasing transparency in the decision-making process. However, while the King has accepted the report, he has not yet acted on it and those who committed the crimes have not been prosecuted in the courts. Most importantly, the IER's remit does not include the current complaints of government abuse, particularly against the Islamists suspected of terrorism (Malka and Alterman, 2006, pp.49-50; Slyomovics, 2005, p.197). ${ }^{16}$

Looking closer at the role of the civil society in the IER, the commission in fact came about through lengthy consultations between the throne and certain elements in civil society, including former political prisoners, while the political parties were hardly involved at all. The idea came from Driss Benzekri, a former Marxist-Leninist activist who had been imprisoned for 17 years (between 1974 and 1991). Following his release, he and a group of former detainees offered a 'deal of historic importance' (Hazan, 2006, p.3) to the monarchy: they would collaborate with the regime and even support an amnesty of their former torturers and their superiors on the condition that the throne would strongly pursue democratisation. They believed that the domestic system could be reformed from within and wanted to use the IER as a lever for democratic change. The selection of the IER's 17 commissioners reflected the alliance (or co-optation) between elements of civil society and the throne: six of the IER commissioners were former political prisoners and former far-left activists, some of whom had been forced into exile for years.

However, the IER also led to a split within the human rights movement, as the AMDH, a number of former victims, human rights activists, Islamists and most of the victims from the Western Sahara complained that the IER had granted impunity to the torturers and their superiors. They accused the IER of distorting the transitional justice mechanisms to protect those responsible for the repressive system. For the critics, installing the rule of law meant exacting justice for past crimes. The focus of the IER, as with the 1999 Indemnity Commission, was primarily on the financial measures of compensation and the symbolic gestures intended for the victims and their families, not the prosecution of those responsible (Slyomovics, 2005, p.197). The AMDH also disagreed with the IER's careful approach, in which the victims were not allowed to 
name their torturers. The association decided to organise parallel public hearings, called the 'Completely Free Testimonies for Truth', and there has been no retaliation against those making the denunciations. It could therefore be argued that despite, or precisely because of, its shortcomings, the IER opened the space for civil society to express calls for greater political accountability without the threat of repression.

However, it could also be argued that the more the political arena is liberalised, the more awkward it becomes to oppose the government. The historic demands of the opposition - the democratisation of the system - has become the reference system of the monarchy itself; the traditional oppositions, i.e., the political parties, have been disqualified in favour of civil society, of which it could always be claimed that it is not representative (Catusse and Vairel, 2003, pp.84-85). Furthermore, the continued use of royal pardons for political prisoners emphasises the raw power of the King's extraconstitutional and extrajudicial gestures and his position as the final arbiter (Slyomovics, 2005, p.198).

The work of the NGO Transparency Maroc is another important example of associations working in the field of public sector accountability. Although the government refused to grant it legal status for two years (from 1996 to 1998), it has conducted numerous studies and regularly publishes the results of corruption perception surveys (in 2005, Morocco took up the 78th rank out of 158 countries (Herradi, 2005)). Together with many other associations, it has long called for the strengthening of the legal framework. Indeed, Denoeux (2000, p.169) argued that civil society was "the single most important factor that has brought visibility to the issue of corruption and placed it on the political agenda". In particular, Maroc 2020 and Transparency Maroc were instrumental in rallying civil society around this issue and in enhancing the public awareness of the costs of corruption for Morocco's economic and political development. They did this in a nonconfrontational, problem-solving attitude that emphasised coalition building (including the cooperation with donors as well as with the CGEM) while managing to avoid co-optation by the Makhzen. ${ }^{17}$ They also benefited from close personal relationships within the government administration, given that many advocacy group members had joined the government of alternance formed in April 1998, which brought the former leftist opposition into power (Denoeux, 2000, pp.169-170, 178; Catusse, 2002, p.11).

The achievements include reforms in the justice sector. They were recently followed by the cabinet's adoption of several anticorruption laws. They pertain to the mandatory declaration of personal wealth by each public official and their inspection by the Administrative Court (Cour des Comptes), the reform of the procurement laws to increase transparency in public sector procurement, as well as the ratification of the UN Convention against Corruption, which calls for a greater participation of civil society in the fight against corruption. Furthermore at the time of writing, a Central Commission for the Prevention of Corruption (Instance centrale de prévention de la corruption) was due to be set up shortly. Its tasks include alerting the justice system about possible cases, although they remain vaguely defined and the commission's degree of independence from the executive branch is not clear (Qattab, 2007; Rerhaye, 2007).

It remains to be seen whether these most recent measures will provide a radical break with earlier sporadic anticorruption measures. Those usually ended in the fall of a scapegoat to satisfy public opinion and had the effect of personalising and depoliticising corruption. The perpetrators' alleged misdeeds were not documented publicly and it was the Ministry of the Interior who decided on which of the local councillors accused of 
corruption or fraud should step down. This procedure arguably completely marginalised the role of the citizens in holding their representatives to account. It has also been suggested that these campaigns provided the Makhzen with a convenient way to eliminate political opponents or economic rivals (Catusse, 2002, p.20).

In general, the pro-democracy CSOs suffer from a lack of widespread popular support for their causes (see Hegasy, 1996, p.335; Naciri et al., 2004, p.123). Pro-democracy NGOs are overwhelmingly the province of the secular, liberal elite, and their (highly abstract) discourse and activities (mainly workshops and reports) often seem alien to the real-life concerns of the population. Historically, repression, precarious funding (especially due to the donor policy of not funding recurrent expenditures) and weak management (the lack of internal democracy) also hampered their influence, despite recent attempts at professionalisation (El-Glaoui and Lamy, 1999, p.160; Naciri et al., 2004, pp.132, 143; Ayee et al., 2004, p.133).

Most importantly, the monarchy has contributed to divisions within civil society. King Hassan II arguably employed the same strategy as with the political parties, i.e., to allow and even encourage the multiplication of associations in order to hinder the emergence of any single NGO that might develop a monopoly, or of a unified and coherent NGO elite. The Makhzen also tried to 'domesticate' the notion of civil society and take away its connotation of potential contrepouvoir by integrating its discourse into the official government language and conferences. A further tactic was to create new institutions such as 'Consultative Councils' (e.g., for human rights in 1990). They allowed the co-optation of influential personalities while marginalising its most radical members, and the councils' 'consensual recommendations' served to legitimise the government's actions. They also afforded the King the opportunity to modernise his historic function of ultimate arbiter. By taking the initiative, the King introduced new tensions and divisions within civil society, whose representatives could not agree on a unified response. For example, the creation of the Consultative Council on Human Rights divided the human rights groups into those that agreed to take part in it (the OMDH and LMDDH) and those that did not (the AMDH). The creation of the Ministry of Human Rights in 1993 can also be interpreted in this light, as can arguably the establishment of the IER. ${ }^{18}$ In short, the older practices and notions of government, such as royal arbitration, distort the Western notions of governmental accountability (Denoeux and Gateau, 1995, p.33ff.; Denoeux and Maghraoui, 1998; Mouaqit, 2004, p.94; Ayee et al., 2004, p.136).

To sum up the findings, we have seen that there are several different sectors that constitute civil society in Morocco, which sometimes work side by side but can rarely coalesce in a sustained fashion. This can partly be explained by the government's strategy to 'divide and rule', i.e., to encourage the development of competing associations to those that are potentially destabilising. Although it is often referred to as 'associative movement' (le mouvement associatif), civil society in Morocco today is still very divided, characterised by diverging objectives and even hostilities, so that it cannot really be called a movement for democratic change. 


\section{The scope for accountability in state-civil society partnerships}

There is substantial literature (see Ackerman, 2004, p.449ff.) that argues that 'state-society synergy' is one of the best ways to strengthen government performance accountability. This last part of the paper will examine the Moroccan experience in this area, which requires looking more closely at the 'service NGO' sector. I will not describe in detail here the many subtypes of 'service NGOs', such as microcredit associations, farmer cooperatives, or local village associations. Suffice it to say that in general, their main concerns are to provide basic services and infrastructure, both in the rural and urban context and, to a lesser extent, to create jobs. Hence, it many settings, they engage in co-production relationships (i.e., in which citizens and government agencies act together to produce results (Krishna, 2004, p.4)) with the local governments or provincial delegations of ministerial delegations, such as education (in organising literacy classes; see Herzenni, 2006, p.275ff.) and health. The newly created Social Development Agency (ADS) also disburses funds through the local associations.

However, there are serious shortcomings with regard to the internal governance mechanisms of many such associations (with regard to the holding of annual meetings, keeping records, financial management and the monopolisation of information by the president). ${ }^{19}$ Apart from the lack of capacity in terms of finances and human resources, this also raises the issue of how they would be motivated to ask for more public sector accountability if they themselves are often not accountable to their beneficiaries and donors. Indeed, this is compounded by the fact that many leaders of the local associations are, in fact, using their associations as a base to build popular support for getting (re)elected as local councillors. Indeed, "creating an association is a means to buy (political) "virginity' for oneself, and to conquer the political field" (Bourjeois and El Kam, 2000, p.13, and author's fieldwork observations).

Despite these shortcomings, the government recently decided to encourage partnerships between its administration and such associations. In 2003, the Prime Minister sent a circular to the Ministers and Secretaries of State entitled 'Partnership between the State and Associations'. The sectors of activity for these new types of partnerships include combating poverty and social exclusion, adult literacy classes and informal education, income-generating activities and the development of infrastructure and basic social services.

The associations that work in these sectors can receive government grants under detailed partnership agreements. The selections to disburse the funds are to be made according to the criteria of transparency, objectivity and direct benefit to the target populations. It is clear that this circular has made it much easier for associations to establish partnerships with government administrations (Ben Youssef, 2003). However, so far, there are not many examples of such partnerships, mainly due to confusion about how to enact these 'partnerships' and the lack of institutional and monetary support. ${ }^{20}$ Instead, many of the existing partnerships rely on individual relationships, resulting in a clientelistic method of operation, which is both unstable and can easily lead to 'soft' corruption (Bennett, 2005; author's fieldwork observations). As has happened in other developing countries, there is thus a danger that the government administrations co-opt the CSOs and prevent them from taking up postures and activities that are inconvenient for the government (Manor, 2002, p.6). 
In terms of partnerships with local governments, the legal framework in this area has also been reformed recently. Under the new Municipal Charter of 2002 (Article 41, Paragraph 3), the Commune Council can enter into partnership agreements with the local associations. However, the Ministry of the Interior still needs to approve each partnership agreement and the local authorities have no legal right to audit the subsidies they give to the associations (El Yaagoubi and Harsi, 2006, pp.203-204; Filali Meknassi, 2002, p.21). Vice versa, the local village associations have little incentive to hold the local government accountable in terms of its spending choices and project implementation (see also Abbadi, 2003a, p.107). There are no institutional practices that promote and value the local associations by formally associating them with management or decision-making in public affairs, as in some other countries (e.g., the participatory budgeting experience in Porto Alegre). Rather, the local development associations are generally seen by the elected councillors as instruments for political competition. This means that they try to co-opt them (by presiding over them themselves or reducing them into the appendix of a party) or marginalise them (Ben Ali, 2005, pp.4-5). A roundtable discussion among civil society actors (Espace Associatif, 2003, p.57) established that most often, the local authorities and political parties give funds to associations for electoral ends or to hide suspicious activities from public opinion. A local council president needs considerable political capital if he is to manage the latent contradiction inherent in submunicipal participatory structures, namely, between the risk of the development of a counterpower to the Commune Council and the potential for the Council to assert itself as a structure of participatory democracy which would, in turn, increase the legitimacy of its activities (FEMISE, 2004, p.192; Abbadi, 2003b, p.51; RTI, 2002, p.6). With regard to so-called 'participatory' development projects, which often require the constitution of local village associations, it has been argued that they contribute to an erosion of accountability at the local level (see Manor, 2004). In Morocco, in general, such projects do not take into account the existing planning mechanisms, such as the four-year Economic and Social Development Plans that the municipalities are supposed to implement and for which they could be held accountable for (author's fieldwork).

An interesting innovation is the 'Espaces Associatifs' in Al Haouz province. These are federations of associations at the municipal, cercle (a group of rural municipalities) and provincial levels, which were set up to better coordinate their activities among themselves and with the municipalities and the provincial authorities. However, based on the author's fieldwork observations, so far, they seem to be 'empty shells' and are used more for control purposes (by the Ministry of the Interior) than fostering a climate conducive to information sharing and partnerships. In short, the horizontal accountability between the local government and CSOs in Morocco is not yet supported by honest and regular information exchange, and responsibility and authority-sharing arrangements are not clearly laid out (Krishna, 2004, p.22). ${ }^{21}$ It is also not the case yet that the central government encourages civil society at the local level as a means to hold the local governments to account, which could result in better service delivery, as happened in Brazil, for example (Tendler, 1997, discussed in Bergh, 2004, p.787).

To conclude this section, given the evidence presented here, local state-civil society partnerships in Morocco are still at the 'co-production' stage. Civil society at this level is, for the most part, not yet engaged in 'societal accountability' (Peruzzotti and Smulovitz, 2000, cited in Ackerman, 2004, p.450) and the government has only very recently started 
to experiment with the idea of institutionalising 'co-governance mechanisms for accountability', where societal actors participate directly in the core functions of the government itself. ${ }^{22}$

\section{Outlook and conclusions}

Indeed, I conclude this paper by briefly referring to the National Human Development Initiative or known as Initiative Nationale pour le Développement Humain (INDH), which the King launched in May 2005. It is designed to improve the socioeconomic conditions in the targeted poor areas (five million people at a cost of US\$1.1 billion through to 2010). It is promoting a new participatory local governance mechanism designed to empower the local communities and municipalities. To this end, local human development committees have been created in all provinces and in each municipality concerned. They include local civil society representatives and are responsible for setting local priorities, selecting projects for financing, establishing the relevant institutional agreements, and monitoring and evaluating project management. Although an attempt has been made to establish a relatively transparent procedure for setting priorities and selecting projects, the regional representatives of the Ministry of the Interior (the walis appointed by the King) manage the funds in the first phase. There is also the risk that the national government will simply repackage the projects conceived in the capital as INDH activities and feed them into the existing regional patronage networks. Indeed, the fact that the INDH is not structured around the elected local municipalities presents the danger of 'administrative decentralisation without political devolution' and the resulting accountability gaps (Malka and Alterman, 2006, pp.50-51; Martín, 2006; CSIS, 2006, p.4). This very preliminary assessment of the INDH would mean that civil society's scope for increasing public sector accountability, at least at the local level, is likely to experience only very gradual improvement over the next few years.

To conclude, this paper has discussed three broad reasons for the current state of affairs: limited public sector accountability mechanisms within the government; the fragmented nature of Moroccan 'civil society'; and the lack of agreement on the way forward, as illustrated by the Equity and Reconciliation Commission example and the nature of state-civil society partnerships.

\section{References}

Abbadi, D. (2003a) 'Appui des associations à la gestion locale', in Espace Associatif (Ed.) Quelle contribution associative à la réduction du déficit de la démocratie locale? Tables Rondes 2002, Rabat: Espace Associatif and Fondation Friedrich Ebert, pp.105-114.

Abbadi, D. (2003b) 'Rôle des associations dans la gestion locale', in Espace Associatif (Ed.) Quelle contribution associative à la réduction du déficit de la démocratie locale? Tables Rondes 2002, Rabat: Espace Associatif and Fondation Friedrich Ebert, pp.49-56.

Acharya, A., Lavalle, A.G. and Houtzager, P.P. (2004) 'Civil society representation in the participatory budget and deliberative councils of São Paulo, Brazil', IDS Bulletin, Vol. 35, No. 2, pp.40-48.

Achy, L. (2005) 'The process of making market-enhancing laws in Morocco', ZEF Projekt: Verbesserung der Wirtschaftsgesetzgebung in arabischen Ländern, University of Bonn, Bonn: Zentrum für Entwicklungsforschung. 
Ackerman, J. (2004) 'Co-governance for accountability: beyond "exit" and "voice", World Development, Vol. 32, No. 3, pp.447-463.

Association Démocratique des Femmes du Maroc (ADFM) (Ed.) (2003) Budget participatif: Parlement et société civile: quels mécanismes de collaboration? Actes de l'atelier international, Rabat 13-14 Juin 2002, Casablanca: Association Démocratique des Femmes du Maroc (ADFM).

Axtmann, D. (2003) 'Die gesellschaftliche Anbindung der marokkanischen Parteien', in Deutsches Übersee-Institute (Ed.) Working Paper, Forschungsgruppe: 'Informelle Politik und politische Parteien im interregionalen Vergleich', Deutsches Orient-Institut.

Ayee, J., Boukongou, J-D., Catusse, M., Eboko, F., Janati, M.I. and Toulabor, C. (2004) 'Les sociétés civiles du Sud: Un état des lieux dans trois pays de la ZSP - Cameroun, Ghana, Maroc', in R. Otayek (Ed.) Centre d'étude d'Afrique noire, Institut d'études politiques de Bordeaux and Direction Générale de la Coopération internationale et du Développement, Ministère des Affaires étrangères, France.

Bartels, L. (2004) 'A legal analysis of human rights clauses in the European Union's Euro-Mediterranean association agreements', Mediterranean Politics, Vol. 9, No. 3, pp.368-395.

Belkouch, E. (2006) 'Droit de l'Homme et démocratisation au Maroc: Bilan et perspectives', In 50 ans de développement humain au Maroc et perspectives pour 2025, Rabat, pp.31-42.

Ben Ali, D. (2005) 'Civil society and economic reform in Morocco', ZEF Projekt: Verbesserung der Wirtschaftsgesetzgebung in arabischen Ländern, University of Bonn, Bonn, Germany: Zentrum für Entwicklungsforschung.

Ben Youssef, M.S. (2003) Le financement des associations par les pouvoirs publics au Maroc, Rabat: Espace Associatif.

Benjelloun, M.O. (2006) 'Etat, démocratisation et société civile au Maroc', Paper Presented at the Democratic Developmental State in Africa Conference, Cairo, 25-26 November.

Bennett, N.S. (2005) 'A politic of partnership: NGO-state relations in Morocco (final version)', Paper Presented at the CSID Sixth Annual Conference 'Democracy and Development: Challenges for the Islamic World', Washington, DC, 22-23 April.

Bergh, S. (2004) 'Democratic decentralisation and local participation: a review of recent research', Development in Practice, Vol. 14, No. 6, pp.780-790.

Bergh, S.I. (2006) 'MENA region case-study: Morocco', Paper Presented at the Brenthurst Foundation Conference on 'Globalisation and Economic Success: Policy Options for Africa', Cairo, Egypt, 13-14 November.

Blair, H. (2000) 'Participation and accountability at the periphery: democratic local governance in six countries', World Development, Vol. 28, No. 1, pp.21-39.

Bourjeois, J-B. and El Kam, H. (2000) 'Etude préalable au programme concerté Maroc: Extraits du Rapport de mission', Programme Concerté Maroc, http://www.pcm.ma/ (accessed 19 May 2005).

Carnegie Endowment for International Peace and Fundación para las Relaciones Internacionales y el Diálogo Exterior (FRIDE) (2006) 'Morocco', Arab Political Systems: Baseline Information and Reforms, Washington, DC and Madrid.

Catusse, M. (2002) 'Affaires, scandales et urnes de verre à Casablanca. Les ambiguïtés de la démocratie locale à l'ère de la bonne gouvernance', EUI Working Papers, Mediterranean Programme Series, RSC No. 2002/38, European University Institute.

Catusse, M. and Vairel, F. (2003) “"Ni tout a fait le même, ni tout a fait un autre”. Métamorphoses et continuité du régime Marocain', Maghreb-Machrek, Vol. 175, pp.73-91.

Cavatorta, F. (2005) 'The international context of Morocco's stalled democratization', Democratization, Vol. 12, No. 4, pp.548-566.

Cavatorta, F. (2006) 'Civil society, Islamism and democratisation: the case of Morocco', Journal of Modern African Studies, Vol. 44, No. 2, pp.203-222. 
Center for Strategic and International Studies (CSIS) (2006) Middle East Program: Morocco Trip Report. 'The U.S., the EU and Middle East Reform: What Can We Learn from Morocco?', Washington, DC, March.

Chadli, E. (2001) La société civile ou la quête de l'association citoyenne, Essais et Etudes No. 32, Rabat: Faculté des Lettres et Sciences Humaines, Université Mohamed V.

Chaker, A. (2006) 'Etude sur l'intermédiation financière au bénéfice des associations (Synthèse)', Forum des Alternatives Maroc, http://www.forumalternatives.org/article17.html (accessed 3 August 2006).

Chammari, K. and Kéfi, R. (2006) 'Etonnant Maroc', Jeune afrique, 17 September.

Cherkaoui, M. and Ben Ali, D. (2007) 'The political economy of growth in Morocco', The Quarterly Review of Economics and Finance, Vol. 46, pp.741-761.

Democracy Reporting International (DRI) and Transparency Maroc (TM) (2007) Preliminary Statement on the 7 September 2007 Elections to the House of Representatives, Morocco, http://www.mena-electionguide.org/mena_files/mena_file_946 _30.pdf (cited 18 November 2007).

Denoeux, G. (2000) 'The politics of Morocco's "fight against corruption", Middle East Policy, Vol. VII, No. 2, pp.165-189.

Denoeux, G. and Gateau, L. (1995) 'L'essor des associations au Maroc: à la recherche de la citoyenneté?', Maghreb-Machrek, Vol. 150, October-December, pp.19-39.

Denoeux, G. and Maghraoui, A. (1998) 'King Hassan's strategy of political dualism', Middle East Policy, Vol. V, No. 4, pp.104-130.

Denoeux, G. and Payne, R. (2003) 'Democracy and governance assessment of Morocco: final report', Work Conducted under USAID Contract No. AEP-I-00-99-00041-00, General Democracy and Governance Analytical Support and Implementation Services Indefinite Quantity Contract, submitted to Peter Kresge, USAID/Morocco, Burlington, Vermont: ARD, Inc., 15 June.

Denoeux, G.P. and Desfosses, H.R. (2007) 'Rethinking the Moroccan parliament: the kingdom's legislative development imperative', The Journal of North African Studies, Vol. 12, No. 1.

Elbayar, K. (2005) 'NGO laws in selected Arab States', The International Journal of Not-for-Profit Law, Vol. 7, No. 4.

El-Glaoui, H. and Lamy, A. (1999) 'Field report: contributing to a culture of debate in Morocco', Journal of Democracy, Vol. 10, No. 1, pp.157-165.

El Yaagoubi, M. and Harsi, A. (2006) 'Rapport sur le cadre conceptuel, législatif et réglementaire des processus de décentralisation et de régionalisation au Maroc', In 50 ans de développement humain au Maroc et perspectives pour 2025, http://www.rdh50.ma/fr/pdf/contributions/ GT10-6.pdf (accessed 20 February 2006).

Espace Associatif (Ed.) (2003) Quelle contribution associative à la réduction du déficit de la démocratie locale? Tables Rondes 2002, Rabat: Espace Associatif and Fondation Friedrich Ebert.

Filali Meknassi, R. (2002) 'Etude sur le cadre juridique et institutionnel des associations au Maroc', Unpublished Paper dated 28 March 2002, World Bank Morocco Country Office.

Forum Euro-Méditerranéen des InstitutS Economiques (FEMISE) (2004) Profil Pays Maroc, Institut de la Méditerranée, France; Economic Research Forum, Egypt, and Femise Coordinators.

Garon, L. (2003) Dangerous Alliances: Civil Society, the Media \& Democratic Transition in North Africa, London: Zed Books.

Hammoudi, A. (1997) Master and Disciple: The Cultural Foundations of Moroccan Authoritarianism, Chicago: The University of Chicago Press.

Hamzawy, A. (2007) 'The 2007 Moroccan parliamentary elections: results and implications', Carnegie Endowment for International Peace, 11 September, http://www.carnegieendowment .org/files/moroccan_parliamentary_elections_final.pdf (cited 18 November 2007). 
Hawthorne, A. (2004) 'Middle eastern democracy: is civil society the answer?', Carnegie Papers Middle East Series No. 44, Democracy and Rule of Law Project, Washington, DC: Carnegie Endowment for International Peace.

Hazan, P. (2006) 'Morocco: betting on a truth and reconciliation commission', Special Report 165, Washington, DC: United States Institute of Peace.

Hegasy, S. (1996) 'Staat, Öffentlichkeit und Zivilgesellschaft in Marokko: Zur Rolle der sozio-kulturellen Opposition', Schriften des Deutschen Orient Instituts, Hamburg: Deutsches Orient Institut.

Hegasy, S. (1998) 'Civil society and monarchy: the case of Morocco', Civil Society, Vol. 7, No. 76, pp.14-16.

Hegasy, S. (2007) 'Young authority: quantitative and qualitative insights into youth, youth culture, and state power in contemporary Morocco', Journal of North African Studies, Vol. 12, No. 1, pp.19-36.

Herradi, J.E. (2005) 'Corruption: Le Maroc s'enlise en 2005', L'Economiste, 19 October.

Herzenni, A. (2006) 'Evolutions du partenariat et modalités de pilotage et de gestion du développement humain', In 50 ans de développement humain au Maroc et perspectives pour 2025, http://www.rdh50.ma/fr/pdf/contributions/GT10-7.pdf (accessed 20 February 2006).

Holden, P. (2005) 'Hybrids on the rim? The European Union's Mediterranean aid policy', Democratization, Vol. 12, No. 4, pp.461-480.

Juris-Classeur Marocain (1958) 'Dahir No. 1-58-376 (15 Novembre 1958, 3 joumada I 1378) réglementant droit d'association (B.O. 27 Novembre 1958, rectif. B.O. 9 janvier)', www.ngoregnet.org/Library/Morocco_law.doc (accessed on 13 December 2006).

Kasriel, M. (2006) 'Exclusion sociale, pauvreté, analphabétisme: processus d'exclusion', In 50 ans de développement humain au Maroc et perspectives pour 2025, http://www.rdh50.ma/ fr/pdf/contributions/GT7-2.pdf (accessed 20 February 2006).

Krishna, A. (2004) 'Partnerships between elected local governments and community-based organizations: exploring the scope for synergy', Social Development Papers: Community Driven Development No. 52, Washington, DC: World Bank, February.

Lacroix, T. (2005) Les réseaux marocains du développement: Géographie du transnational et politiques du territorial, Paris: Presses de Sciences Po.

Layachi, A. (1998) State. Society \& Democracy in Morocco: The Limits of Associative Life, Georgetown University, Washington, DC: Center for Contemporary Arab Studies.

Louissi, T. (2001) Rôle de la Société Civile dans le Développement Régional, Mémoire pour l'obtention du Diplôme des Etudes Supérieurs Approfondies, Université Mohamed Ier.

Maghraoui, A. (2001) 'Political authority in crisis: Mohammed VI's Morocco', Middle East Report No. 218, Vol. 31, No. 1, pp.12-17.

Maghri, A. (2007) 'Gouvernance: un rapport accablant pour l'Etat', La vie éco, 26 January.

Malka, H. and Alterman, J.B. (2006) Arab Reform and Foreign Aid: Lessons from Morocco, Significant Issues Series, Washington, DC: The CSIS Press, Center for Strategic and International Studies, Vol. 28, No. 4.

Manor, J. (2002) 'Partnerships between governments and civil society for service delivery in less developed countries: cause for concern', Paper Presented at the 'Making Services Work for Poor People', World Development Report (WDR) 2003/04 Workshop, Oxford, 4-5 November.

Manor, J. (2004) 'User committees: a potentially damaging second wave of decentralisation?', The European Journal of Development Research, Vol. 16, No. 1, pp.192-213.

Martín, I. (2006) 'Morocco: the bases for a new development model? (I): the National Initiative for Human Development (INDH)', Area: Mediterranean \& Arab World, ARI 35/2006, Date: 4/5/2006, Madrid: Real Instituto Elcano, http://www.realinstitutoelcano.org/analisis/ 947/947_Martin_MoroccoI.pdf. 
Mouaqit, M. (2004) 'Le mouvement des droits humains au Maroc', in M-A. Roque (Ed.) La société civile au Maroc: L'émergence de nouveaux acteurs de développement, Editions Publisud, pp.85-102.

Naciri, R. (1998) 'The women's movement and political discourse in Morocco', United Nations Research Institute for Social Development Occasional Paper, Geneva: United Nations Development Programme, Vol. 8.

Naciri, R., Janjar, M.S. and Mouaquit, M. (2004) 'Développement démocratique et action associative au Maroc: eléments d'analyse et axes d'intervention', Montréal: Rights \& Democracy (Canada), and Espace Associatif (Morocco).

Newell, P. and Bellour, S. (2002) 'Mapping accountability: origins, contexts and implications for development', IDS Working Paper 168, Brighton: Institute of Development Studies.

Oxford Business Group (2005) Morocco - Country Profile, http://www.oxfordbusinessgroup.com/ country.asp?country=27 (cited 13 July 2005).

Peruzzotti, E. and Smulovitz, C. (2000) 'Societal accountability in Latin America', Journal of Democracy, Vol. 11, No. 4, pp.147-158.

Piriou-Sall, S. and Sallier, J-C. (1998) 'Chpt 3: Décentralisation et développement rural au Maroc', Report No. 16303-MOR: Royaume du Maroc: Stratégies de développement rural (1998-2010), Rapport de synthèse (en trois volumes) Volume 3 Annexes, The World Bank.

Qattab, T. (2007) 'Anticorruption: Le Maroc ratifie la convention ONU', L'Economiste, 2 February.

Rerhaye, N. (2007) 'Un cadre juridique pour lutter contre la corruption - Transparence, j'écris ton nom', Libération, 2 February.

Research Triangle Institute (RTI) (2002) 'Le mouvement associatif au Maroc', Projet: Appui au renforcement de la décentralisation et de la démocratie locale, USAID and Ministère de l'Intérieur, Direction Générale des Collectivités Locales.

Romdhane, D. (2004) 'Supporting penal and prison reform in North Africa: Algeria and Morocco', in C. Ferguson and J.O. Isima (Eds.) Providing Security for People: Enhancing Security Through Police, Justice, and Intelligence Reform in Africa, Shrivenham: Global Faciliation Network for Security Sector Reform, pp.67-74.

Royaume du Maroc (2002) Ministère des Finances et de la Privatisation, Direction du Budget, Division des secteurs sociaux, Etat/Associations: Les balises d'un partenariat pérenne et solidaire.

Royaume du Maroc, Ministère de l'Intérieur, Direction Générale des Collectivités Locales (DGCL) (2004) Collectivités Locales en Chiffres 2002, Rabat: Centre de Documentation des Collectivités Locales.

Salam, N. (2002) 'Civil society in the Arab world: the historical and political dimensions', Occasional Publications 3, Cambridge, MA: Islamic Legal Studies Program, Harvard Law School.

Santucci, J-C. (1991) 'Les associations régionales marocaines, un nouveau cadre pour le clientélisme?', in Y. Lacoste and C. Lacoste-Dujardin (Eds.) L'Etat du Maghreb, Casablanca: Editions le Fennec, pp.354-355.

Sater, J. (2002) 'The dynamics of state and civil society in Morocco', Journal of North African Studies, Vol. 7, No. 3, pp.101-118.

Schedler, A. (1999) 'Conceptualizing accountability', in A. Schedler, L. Diamond and M. Plattner (Eds.) The Self-Restraining State: Power and Accountability in New Democracies, Boulder: Lynne Rienner.

Skalli, N. (2005) 'Participatory budget and the role of civil society', Paper Presented at the Dialogue of MENA Parliamentarians on Reform and Public Finance Management: Workshop Report, Rabat, 29-30 April 2004.

Slyomovics, S. (2005) The Performance of Human Rights in Morocco, Philadelphia: University of Pennsylvania Press. 
Sweet, C. (2001) 'Democratization without democracy: political openings and closures in modern Morocco', Middle East Report No. 218, Vol. 31, No. 1, pp.22-25.

Tendler, J. (1997) Good Government in the Tropics, Baltimore: The Johns Hopkins University Press.

UNDP Maroc (2006) Rapport de Développement Humain 2005: Femmes et Dynamiques du Développement, http://www.pnud.org.ma/pdf/rapports/RAP_DEV_HUM_Fr_05.pdf.

UNDP Maroc and Périer, F. (2005) Etude sur le bénévolat et le volontariat au Maroc, Rabat: UNDP.

Willis, M. (2002a) 'Political parties in the Maghrib: ideology and identification. A suggested typology', Journal of North African Studies, Vol. 7, No. 3, pp.1-28.

Willis, M. (2002b) 'Political parties in the Maghrib: the illusion of significance', Journal of North African Studies, Vol. 7, No. 2, pp.1-22.

World Bank (2003) 'Note sur la gouvernance et la société civile', Unpublished Document, Rabat: World Bank, Morocco Country Office.

World Bank (2004) 'State-society synergy for accountability: lessons for the World Bank', World Bank Working Papers No. 30, Washington, DC: World Bank.

Yom, S.L. (2005) 'Civil society and democratization in the Arab world', The Middle East Review of International Affairs (MERIA), Article 2, Vol. 9, No. 4.

\section{Notes}

1 For the sake of greater clarity and consistency, we have not used the terminologies of 'direct vertical accountability', 'society-driven horizontal accountability' and 'diagonal accountability' to describe these three mechanisms (as introduced in World Bank, 2004, pp.9-10).

2 See Newell and Bellour (2002, p.7ff.) for a comprehensive discussion of 'vertical' and 'horizontal' accountability.

3 See Benjelloun (2006, pp.25-26) for a chronology of these new institutions.

4 Denoeux and Maghraoui (1998) discussed the 1992 constitution and its strengthening of Parliamentary powers, but also noted that the new upper house (the Chamber of Councillors) can be expected to play the role of 'defender of the throne' and enhance the regime's legitimacy. See Achy (2005) for a detailed account of the lawmaking process in Morocco. A recent study is more optimistic, noting that the Parliament is slowly becoming more proactive and assertive as a vehicle for accountability and that there are growing signs of a sense of corporate identity and of a nascent 'parliamentary culture' that transcends political divisions. However, it also notes that the existence of two chambers creates two main, interrelated types of problems for the Parliament: a legitimacy/credibility gap and an effectiveness/internal capacity deficit (Denoeux and Desfosses, 2007, pp.99-100).

5 The King is also the highest religious authority in the country, as the 'amir al-mou'minin' or 'Commander of the Faithful'. See Garon (2003) and Hammoudi (1997) for the importance of religious prestige and allegiance to explain the monarchy's continued power. See Cherkaoui and Ben Ali (2007, p.744) for a discussion of the bei'a, the contract of allegiance between the King and the people, which is renewed every year. The King insures public security and order in return for the people's obedience. Hegasy (2007) presents evidence that among young Moroccans, the authority of King Mohamed VI is based more on his youthful image than the traditional means of ensuring allegiance.

6 See Salam (2002) for a discussion of the concept of 'civil society' in Islamic societies. On the strength or weakness of civil society in the Middle East and North Africa, see Hawthorne (2004) and Yom (2005). 
7 The following is based on UNDP Maroc and Périer (2005, p.14). See also Ayee et al. (2004, p.53ff.), El-Glaoui and Lamy (1999, pp.159-160), Louissi (2001, p.80ff.) and Naciri et al. (2004, p.110).

8 As for the current EU support for human rights and democracy in Morocco, the MEDA Democracy Programme was incorporated into the European Initiative for Democracy and Human Rights in 2000. In 2005, one million euros were made available to support NGOs. Holden (2005, p.466) suggests that the EU's aid strategy can be best described as a promotion of the hybridisation of its partner states: grafting 'modern' liberal forms of governance in certain spheres onto essentially authoritarian structures. See also Bartels (2004).

9 A special type of associations is the Association Reconnue d'Utilite Publique (ARUP). These associations are officially recognised as beneficial to the public at large. This status is given by decree after a lengthy vetting process. In return, these associations can apply for public funds once a year without prior permission and get tax exemptions (Ben Youssef, 2003, p.4; Filali Meknassi, 2002, p.23).

10 The author's survey of 50 village associations in Al Haouz province found that most paid between 1,000 and 2,000 Dh for these documents, but over half had subsequently less than $1,000 \mathrm{Dh}$ in accessible resources for projects.

11 Early on in his reign (in October 1999), the current King called for a new concept of authority based on accountability, human rights and individual freedom. It was supposed to bring the administration closer to the citizens and replace repression with consultation. However, it is not yet implemented in a concrete way (Catusse and Vairel, 2003, pp.81-82, and author's fieldwork observations).

12 As for the 2007 legislative elections, the effort of the Moroccan civil society organisations grouped in the Collectif Associatif pour l'Observation des Elections was met with difficulties, including long negotiations about accreditation procedures with the responsible Comite Consultatif des Droits de l'Homme (CCDH). A joint report by Democracy Reporting International (DRI) and Transparency Maroc (TM) noted that "there has been no progress in this field since 2002, despite long-standing requests by civil society organizations that a clear framework be provided for observation" (DRI and TM, 2007, p.2).

13 We do not have the space here to fully assess the contribution of the women's advocacy NGOs to public sector accountability, but see Ayee et al. (2004), UNDP Maroc (2006, p.65ff.), Skalli (2005) and ADFM (2003). This includes their efforts to mainstream gender in the national budget law.

14 See also Layachi (1998, p.55), Carnegie Endowment for International Peace and FRIDE (2006, pp.15-16) and Mouaqit (2004, p.88).

15 Unless indicated otherwise, the following is based on Hazan (2006). See also Romdhane (2004, p.69) for civil society organisations' work in promoting prison reform in Morocco.

16 Following the Casablanca bombings of May 2003, the courts reintroduced special dispositions restricting civil and political rights. See Slyomovics (2005, p.14ff.) for a discussion of the current police detention practices. Cavatorta (2005, p.563) notes that the 'war on terror' has helped Morocco justify its recent repressive and authoritarian policies.

17 The Collectif Inter-Associatif contre la Corruption (CIACC, or the Network of Associations for the Fight against Corruption) was created by six NGOs in 1997 and now includes over 40 associations (Denoeux and Payne, 2003, pp.70-71).

18 Denoeux and Maghraoui (1998) discuss King Hassan II's strategy to deal with the demands for greater women's and Amazigh/Berber rights, as well as the problems of youth unemployment and labour disputes in the 1990s as further examples of royal arbitration. They call this strategy 'political dualism', as the King strengthens the 'modern' side of Morocco's political system while simultaneously activating its more traditional components (Denoeux and Maghraoui, 1998, p.106).

19 See Newell and Bellour (2002, p.17ff.) for the types of NGO accountability. 
20 See Royaume du Maroc (2002) and Chaker (2006, p.18) for more on the shortcomings of state support for associations. For example, the deconcentrated administrations of the central ministries do not have a lot of latitude in deciding on partnerships that commit their ministries in material and financial terms over a longer period of time.

21 Morocco is no exception among the developing countries. For example, only one out of the six case study countries studied by Blair (2000, p.29) showed "signs of a civil society that is an effective instrument of public accountability at the local level".

22 See Ackerman (2004, p.451ff.) for case studies around the world. Acharya et al. (2004) describes the case of São Paolo, where institutionalised participatory arrangements include the participatory budget and the deliberative policy councils. 